\title{
MORAL PRISMS: ETHICS AND THE OLDER PERSON
}

\author{
Martha Beller Holstein
}

\begin{abstract}
Bioethical discourse, as it relates to common experiences of older people, has tended to focus on conflictive issues as they arise in long-term care. The primary value that this discourse upholds is autonomy, understood as self-direction, and the method of analysis is generally principle- and rulebased. Many good changes in long-term care have come as the result of these efforts. But much of ethical importance is left out, limited by how this form of discourse defines and addresses problems. This paper explores a more expansive view of ethics that attends to context and the particular features of being an older person in ofteninhospitable settings, takes embodiment as a key feature in our moral lives, and situates individuals in important relationships. Using narratives familiar to those who work with older people, especially in clinical settings, this paper will also suggest ways to reconfigure the familiar subject matter of bioethics and long-term care. It will challenge the dominance of existing values and so leave new spaces for ethical action. By bringing in culture, embodiment, and elder subjectivity, it will begin to move from the bioethics of long-term care to a concept of ethics and the older person.
\end{abstract}

KEY WORDS: Ethics; aging; embodiment; Bioethics and long-term care.

* Ph. D. Park Ridge Center for the Study of Health, Faith, and Ethics.

Correspondence: mbh@parkridgecenter.org
Resumen

\section{Prismas morales: ética y adulto mayor}

El discurso bioético, referido a las experiencias comunes del adulto mayor, ha tendido a focalizarse en los temas conflictivos que se originan en la atención de largo plazo.

El principal valor que este discurso sustenta es el de autonomía, entendida como auto-dirección cuyo método de análisis está generalmente basado en principios y reglas. Muchos cambios importantes en el cuidado de largo plazo se han producido como resultado de estos esfuerzos. Pero muchos aspectos de importancia ética han sido dejados al margen, limitado por la forma en que este tipo de discurso defina y aborde los problemas. Este artículo explora una visión más expansiva de la Ética que presta atención al contexto y a las características particulares de ser un anciano, en entornos a menudo inhóspitos; considera la corporalidad como una característica fundamental en nuestra vida moral y sitúa las relaciones interpersonales en un plano de real importancia. Usando un lenguaje familiar para aquellos que trabajan con ancianos, especialmente en ambientes clínicos, este artículo también sugerirá caminos para re-configurar el familiar tema de la Bioética y la atención de largo plazo. Desafiará el dominio de valores existentes, abriendo así nuevos espacios para la acción ética. Al introducir la cultura, la corporalidad y la subjetividad del anciano, la bioética del cuidado de largo plazo se desplazará hacia un concepto de ética y adulto mayor.

PALABRAS CLAVE: Ética; envejecimiento; corporalidad; Bioética y atención de largo plazo. 


\section{Resumo}

\section{Perspectivas morais: ética e idoso}

$\mathrm{O}$ discurso bioético relativo às experiências comuns dos idosos tem mostrado a tendência de restringir-se aos temas conflitivos que se originam da atenção de longo prazo.

O primeiro valor apresentado é o da autonomia, entendida como autogoverno, e o método de análise geralmente é baseado em princípios e regras. Mudanças importantes nos cuidados à longo prazo produziramse como resultado desses esforços, mas muitos aspectos de importância ética não foram contemplados, limitados pelo modelo do discurso e de como foram definidos e apresentados os problemas.

Este artigo explora uma abordagem mais densa da Ética, precisamente aquela que da atenção ao contexto e características particulares do idoso. Apontam-se situações frequentemente inóspitas nas quais se identificam características fundamentais de nossas vidas morais e o alcance relacional das mesmas.

Usando uma linguagem familiar para os que trabalham com idosos, particularmente em clínicas, a presente reflexão faz sugestões sobre novos caminhos para melhor situar a temática bioética e a atenção à longo prazo. Pretende-se, ainda, desafiar o domínio de valores existentes, abrindo novos espaços para a ação ética.

Ao introduzir cultura, personificação e subjetividade do ancião busca-se afastar da bioética do cuidado à longo prazo e aproximar-se do conceito de ética e pessoa idosa.

PALAVRAS CHAVES: Ética; envelhecimento; personificação; Bioética e atenção à longo prazo.

\section{Résumé}

\section{Prismes moraux : éthique et troisième âge}

Le discours bioéthique concernant les expériences communes de l'homme âgé a éte focalisé autour des sujets conflictuels qui se developpent dans des soins à long terme.

La première valeur que ce discours soutient est celle de l'autonomie, entendue comme l'autoguidage et la méthode d'analyse est fondée, de manière générale, sur des principes et des règles. Grâce a ces efforts les soins à long terme ont été bénéficiés de changements importants. Néanmoins beaucoup d' aspects relevants du point de vue éthique sont restés à l'écart, en raison de la forme dont ce discours définit et aborde les problèmes .Cet article explore une vision plus vaste de l'Éthique, celle qui fait attention au contexte et aux caractéristiques particulières de l' homme âgé - dans des milieux souvent inhospitaliers- qui est personnifiée comme une caractéristique clé de nos vies morales et qui situe à l'individu dans des relations importantes .Cet article, en utilisant un langage courant, adressé à ceux qui travaillent avec les adultes âgés, notamment, dans des milieux cliniques ,suggérera également les chemins pour reconfigurer le sujet familier de la bioéthique et les soins à long terme.

Il défiera le domaine des valeurs existantes, en créant des espaces nouveaux pour l'action éthique.

Grâce à l'introduction de la culture, la personnification et la subjectivité de l' homme d'un grand âge, l'article commencera à s'éloigner de la bioéthique des soins à long terme pour s' approcher au concept de l'éthique et de l'adulte âgé.

MOTS CLÉS : Ethique; vieillissement; personnification; Bioéthique et soins à long terme. 


\section{Introduction}

The questions of bioethics and medical ethics are not purely intellectual questions. They are questions of the heart as well as the mind, and questions of social organization, not just the marshalling of arguments. It is harder to reform one's heart or one's society than to improve one's arguments. The sort of disciplined reflection we need on these questions is not merely intellectual (1, pp. 14-15).

In the United States, reflections and teaching about ethics and the older person, as an applied field, are relatively recent, dating roughly from the early 1980s. This attention followed the general surge of interest in applied bioethics that began in the mid 1960s; it evolved transferring and modestly adapting to long-term care the principle and rule-based model developed during the previous decade for use in acute care settings. Now, at the turn of the century, it seems appropriate to acknowledge all that was achieved but also necessary to move in new directions. These new directions encompass close to the ground ethical questions that one encounters in the clinic, the hospital, or the home to questions that touch upon the vast reaches of molecular biology and the threat or promise of "immortality." Joining these issues are questions that involve public policy, which contributes to (or detracts from) the functioning and indeed the moral legitimacy of institutional and other structures. Add to that the complex problems that age, gender, class, race, and other inequalities contribute to the universe of problems compelling attention. More fundamentally this enlarged terrain also challenges the now-familiar bioethics discourse, which not only identifies the problems that come under moral scrutiny but also delimits the strategies we use to analyze them (2).

In this paper, my goals are both more modest and more ambitious than skimming over this range of issues. My orientation, most broadly, uses insights from feminist philosophy and postmodernism(s) to open the scope of ethical discourse so that it is sensitive to context, which may be as intimate as one's body or as broad as one's gender, race, age, or ethnicity. It asks us to think how it might matter ethically that one is an 86-year-old woman from a minority culture. It queries how age itself challenges the standard repertoire of issues in bioethical discourse. And, it moves us from the limited focus of traditional bioethics to a more expansive notion of ethics and the older person. This approach leads to skepticism about overarching truth claims and the practical usefulness of much moral theorizing in guiding specific action. In my re-imagining the world of ethics and old age, I turn to the words of T.S. Eliot in Little Gidding:

We shall not cease from exploration

And the end of our exploring

Will be to arrive where we started

And know the place for the first time

(3, p. 59).

I think this is where we need to be in reflecting about ethics and old age. The territory is familiar; we have mapped the terrain and now we must study it at close range. I will touch upon approximately fifteen years of good work already done while examining that work with different filters. These filters will emphasize the ethics of the everyday, those gestures, behaviors, and words that elevate the seemingly mundane to the ethical importance they merit. These day-to-day behaviors make a common moral world possible and call upon us to make ongoing adjustments through shared conversations. Philosopher Owen Flanagan has likened morality thought about this way to social ecology: "ethics . . . is part of human ecology concerned with saying what contributes to the well-being of humans, human groups, and human 
individuals in particular natural and social environments." (4, p. 36). Standard approaches to bioethics have tended to obscure this kind of ethical analysis. I am also interested in seeing other ways to think about or reconfigure the familiar subjects of bioethics. The last aspect of ethics that I will discuss is the furthest from contemporary approaches to bioethics. This aspect involves cultural norms and ideals and how they shape identity, a feature of human life that supports morally important qualities such as selfrespect and human flourishing (5).

\section{Ethics, aging, the Canon, and beyond}

I start with what should be simple and suggest how age complicates even the simple. To start, let me look at bioethics' traditional territory. Matters of informed consent, truth telling, confidentiality, and so on apply to the old as they do to any other age group, with, however, one important exception. Ageism, or the systematic devaluing of older people, to which I will return below, is not a new phenomena and, despite decades of efforts to eliminate it, it has not disappeared from health care or, indeed, from society. Physicians, for example, still turn to sons and daughters and even relative strangers to ask questionssometimes very personal ones-about competent older people who are very visibly present. Not long ago, a resident doing rounds in a nursing home was interviewing a patient with self-reported abdominal discomfort. He asked her repeatedly if she had had a bowel movement (I might add this is the single most commonly asked question in nursing homes). She just as repeatedly said yes. He then turned to me (the ethics consultant on the team but also this woman's friend) and asked me the same question. I could only respond-ask her!-thereby revealing the importance of the ethics consultant. This matter is a serious one; until such time as people can no longer make sense of their environments, they generally wish to be who they are and have been $(6,7)$; refusing to listen to their responses about their own bodies denies them adult status and belittles personal integrity.

I mention ageism, and give this example, because no encounter with another person comes unmediated by our personal and cultural values, attitudes, prejudices, beliefs, and other conscious or unconscious stereotypes. So even though the standard repertoire of issues in bioethics applies to the elderly as to all others, persisting beliefs about the aged that often are gender-specific mediate their use. Older women's wishes, for example, are less likely to be respected by their doctors than the wishes of their male age peers (8). In art, death assumes a female form (9). Discounting older people has a long and not so illustrious history in medicine. To harm the old, behavior does not have to be as crude as Samuel Shem describes in The House of God but a youthful (and potentially curable) body holds allures for biomedicine that the aging body, nicknamed the GOMER (get out of my emergency room), cannot match (10). It can be as simple as not speaking directly to the patient or as complex as relying on depersonalized care like the use of artificial feeding and nutrition for the person with dementia. Both deny relationship and permit distancing from the aesthetically displeasing aging body (11).

Unlike decision-making in acute care settings, the frequent and varied disabilities that often accompany old age can create problems that are rarely solvable. An uncertain but mostly downhill course places demands on health and social service providers that generally lie outside the scope of bioethics' standard repertoire. Mrs. Porter, at 94, lived in an independent living residence that was attached to a nursing home. As her physical condition deteriorated she insisted on remaining in her apartment. No other option made sense to her. The discussion among her family, her physician, 
the nursing home administrator, the director of nursing, and me was what to do about Mrs. Porter. While she adamantly refused to leave her apartment the administrator feared that she would fall; the family was very anxious about her safety; the attending physician leaned toward the "oops we can easily get in trouble" side. The familiar paradigm that pits autonomy (as self-directed choice) against best interests could only take us part of the way in supporting Mrs. Porter. We honored her choice to stay in her apartment for as long as we could -asking her to also make compromises- and then acted in her best interests when we insisted that she move to the nursing home. But how remiss we would have been if we viewed this moral framing as the only way to consider this situation. It took what philosopher Harry R. Moody has called a communicative ethics (12) or an expressive-collaborative process as opposed to a juridical one described by philosopher Margaret Urban Walker (13) to decide how to honor Mrs. Porter's most fervent wish to stay at home while assuaging the fears of her family, the nursing home administrator, and the attending physician. Regular, open, equal, and free-flowing conversation among members of the team, working with Mrs. Porter, led to a concrete identification of the moral ends we sought in her care and the accommodations necessary by each person involved, including Mrs. Porter. It took recognizing that safety was about more than physical safety and that home, with all its positive connotations, had a psychosocial value that contributed to the continuity of self $(14,15)$. For her part, Mrs. Porter had to agree to more interventions than her conception of independence (which in itself is a problematic ideal) would have allowed but that contributed to meeting her own ends and protected her important relationships with her family and the medical team.

When Mrs. Porter had to move to another setting we had to rethink what her claims for respect and moral worth required of us. This effort took us beyond autonomy as we sought ways to honor her feistiness, her still-strong political commitments, and her need to be reassured about the many symptoms that scared her so much. With Mrs. Porter, it was not the choice itself that ultimately made the difference.

A postmodern ethics exposes the hidden assumptions and presuppositions that support the commitment to autonomy as selfdirection. These cannot account well for frailty, dependency, poverty, professional power, or other individually held moral values $(2,17)$. Not does it account for the social conditions that limit options for some more than for others. Choosing is only one narrow aspect of our moral lives; while Mrs. Porter insisted on getting what she wanted, people in some traditions would not even countenance individual choice as a value worth upholding. For all of us, it is a minimalist concern, perhaps the beginning of moral engagement -for some- but hardly the end of it. Further, the stress on autonomy, as traditionally conceived, often ignores the limits that very sick older people have in making choices and the limits that staff face in virtually all health care settings. The focus on a certain view of autonomy, which rests on a particular description of what kind of people we are, also renders relationships, especially those with family members, as optional rather than an integral part of our identity and the source of obligation.

A situation illustrates this point. A wife is at the bedside of her husband who is close to death. He has been ventilator-supported for about 10 days in the hope that he could be weaned from it shortly. It has become clear to all the medical personnel that weaning him from the ventilator will result in his death. He has designated his wife as his proxy and has indicated that he does not want to be sustained mechanically if he cannot be returned to a condition approximating his prior life. The wife pleads with the attending physician not to take him 
off the vent, at least not just yet. She's not expecting a miracle; she only wants him around a little longer. Some questions come up: Is his wife only the transmitter of his prior wishes? Does the patient's expressed former wishes take precedence over all other important moral goods, like the peace and tranquility of a loving family and their need to begin grieving as they say their goodbyes? What if this man and woman had been happily married for 50 years and had tried to accommodate each other in ways that often involved sacrificing their own desires? Can it just be that this man, as he lay dying, might be less concerned with having his expressed wishes followed than knowing that his wife said her goodbyes in a way that brought her as much comfort as possible in the circumstances? Philosopher Margaret Urban Walker reminds us that preserving integrity is a central moral value for most people (17).

Working with aging people in such settings where the likely outcomes are continued decline and ultimately death is particularly difficult. These situations are usually rife with complexity, ripe with often unexpressed feelings, and marked by conflicting values that have little or nothing to do with making choices. They have to do with getting old in societies that venerate the young; they have to do with the different ways that families grieve and how people in families often do what the others want because that is a more important value than getting their own way. In no situation would I suggest the indefinite use of the ventilator on the man I shall call Mr. Tomas. But I would want to give the family with whom he has shared the last 50 years of his life some time. If relationships count for something, then Mr. Tomas's integrity, self-recognition and self-esteem might better be served by honoring his wife's wishes rather than his own. The power of advance directives (living wills, and durable powers of attorney for health care) is the belief that they allow health professionals and families to do what the patient wanted but what the patient would have wanted, if he had been able to reflect on his actual situation, might have not been about his medical care.

So an alert is in order: how might a preoccupation with autonomy offer us a means of escape, a way to disengage from the more difficult and painful parts of being with ill and dying people? Autonomy lets you stand at arms' distance. While the good parts of an autonomy model are evident it also contains hidden assumptions about what we ought to value and why. These values may not be the most important ones for a good number of people who are ill or dying.

\section{Shifting the prism: another view of ethics and the individual}

Dying exemplifies the limits of a focus on decision-making. Imagine the dying person as yourself. What about all those matters calling for attention: making amends, showing love, paying attention to small matters of comfort. Instead demands of decision-making often divert us. We are kept busy focusing on treatment options, obtaining information (the internet compounds this seemingly unceasing quest for more information as if that search can ease the burden of dying), getting second and even third opinions. This activity leaves little time for the loving gesture, the sheer physicality of a living presence, and the ending of a life narrative (18).

We cannot avoid the fact of death and the facticity of human suffering. Victor Frankl, the prominent founder of logotherapy and a survivor of the Nazi's murderous assaults on not only human life but their efforts to erode human dignity (ultimately it was the Nazis themselves who lost even the remnants of human dignity), told us that there comes a point when all we can do is to adopt an attitude toward our suffering since the suffering itself cannot be taken away (19). 
But in thinking about ethics, we must struggle not to abandon the dying. We all know the language of palliation and hospice. While often wonderful and well-suited to a patient, we still must ask: How often do physicians and other health care providers turf people who are dying to a palliative care specialist or a chaplain they do not know almost without warning? How often do their own doctors abandon them when cure is no longer possible with the careless words, "there is nothing more I can do"? A very elderly physician once said to me, "I teach my residents that they must never let a patient die alone. I have sat beside patients on many a night just holding their hand so that they knew I was with them when they died if they had no one else" ${ }^{1}$. In a recent novel, an elderly gentleman stands silently outside the door of his dying friend's hospital room watching intently, deeply present. When he walks in and they talk for a bit, he asks his friend if there is anything that he can do. The friend said please rub lotion on my very, very dry feet (20). In an interesting irony, perhaps a postmodern ethics can return us to an ancient one when the virtues and ideas about human good and not choice occupied a central place in ethical thinking. Inadvertently, technical medicine and documentation of end of life wishes can become the substitute for compassion and understanding.

\section{The ethics of the everyday}

Let me turn to the ethics of the everyday. Often it does not require a great deal of money to make ethically important actions happen and sometimes it does not even take much time. Such everyday ethics is about a way of life, part of the everyday world in which we live, work, and care about others. It is about rubbing lotion on the feet of our dying friend. We live our morality in our day-to-day lives by exhibiting responsibilities for things open to human care and response (13). Hence, much that is ethical occurs when we are hardly paying attention: how we talk to someone, how we greet an older person, what words we choose to use-the disrespectful he "was" a lawyer; she's "just" using her old social skills; how we work with our colleagues, and how we learn about and honor differences. Philosopher and novelist Iris Murdock observed that the quality of what happens between moments of choice importantly affects those choices (21). These times between moments of choice remain invisible if our primary ethical orientation is directed at rights, conflicts, moments of choice, and on the resolution of conflicts through the top-down application of principles. It cannot, for example, include the denser ethical questions about how health professionals can help older men and women flourish despite loss; and what goals and cultural norms will help achieve those ends.

To do that well requires the attentiveness that writers such as Iris Murdock (21) speak to so eloquently. It does not require adherence to one or another moral theory, which is apt to lay out a number of possibilities if circumstances were ideal. Finely tuned ethics and aging demand finely moral perception; the need to notice what often gets lost when we study older people as objects or when we apply a set of rules to them without really noticing their individual features and thus do not respond appropriately to their concerns. While we cannot respond to all that we notice, without noticing we see only those moral problems predefined by the canon. So I am speaking of an ethics that takes the "whole of our mode of living and the quality of our relations with the world" $(21$, p. 97$)$ as our task. You might ask, how can I do that, how can I take on so much. What you can do, as you set out to consider ethics and aging is to commit yourself to paying attention to the language you use, the expectations that you have, the needs that you recognize, the stories you let others tell. The safety you provide so that an old woman can fall gently may overcome 
much impatience, bitterness, rage, and sadness that often accompanies growing old and becoming frail.

This ethics is about the everyday encounters we have with people who are facing deep adjustments in their lives for all too familiar reasons. There is no urgent dilemma, or interpersonal conflict that demands resolution but rather a genuine encounter with individuals who may have lost a sense of place, a belief that they have some importance in the world. While practice is often much richer than the verbal description of practice, the words spoken in ethics committees, for example, sound as if ethics is only about addressing dilemmas. Does not ethics have something to say when there is no conflict, no interpersonal dilemma? Do we not owe older people some commitment to hear their stories and to help them recover lost meaning through the recreation of a self that fits with their changed circumstances?

Everyday ethics is about the way we structure medical care services in our countries. The practices of medicine can destroy the patient's sense of status as an adult, a self-determining person as we press him to assume the moral and the social identity implied by the illness that is diagnosed. Let's take Henry who had been an ardent tennis player all his life. Since retirement, tennis has assumed even greater importance as he continues to develop his skills. But Henry collapses on the court one day. A heart attack is diagnosed and by-pass surgery performed. Henry recovers quite slowly; tennis seems like another lifetime ago. Other problems compound his recovery. Though none are immediately life threatening, he felt as if he aged about 10 years in 10 days. Can Henry, when he is in the hospital with tubes in every orifice, anxiety his central emotion, and people hovering over him at every moment, especially at 2 a.m. be the same man as the tennis-playing Henry? He is living in his body and that body makes him feel alienated from the great tennis player that he has been. He doesn't recognize the body that he presents to the world. But the body is a source of meaning and meaning-creation. "It is our internal horizon of knowledge and meaning; it is the perspective that we bring to bear on the world" (2). As the result of his physical changes, Henry sees the world differently and that world sees him differently. His wife's concern, the cardiologist's whispers outside his room during rounds; the medical student listening intently to his heart sounds all contribute to profound changes in his social identity. This is a different Henry than the guy that collapsed on the tennis courts just a few weeks ago. His embodied experience generates new meaning and values; for this reason his body's limits and how it affects his relations to others has ethical value (2). To talk about Henry's autonomy at that moment may not be Henry's central moral concern. What do we owe Henry now that his body and its limits have become so determining of what he can do? What ethical possibilities exist in our moment-to-moment encounters with Henry? What physician and philosopher Paul Komesaroff calls microethics (22).

What happens when, in the name of competition, we cut corners? Let us take another patient, Rosa Fabrique. She is mildly demented probably from many small infarcts in her brain. She is also incontinent and severely arthritic. Her latest hospital stay was triggered by a pneumonia that was not resolved. She carries on conversations although at times they are a bit confused. She tugs at her diapers and seems to resent wearing them but the hospital is so shortstaffed that she cannot be toileted regularly. She is often angry especially when around the medical residents who give to her dayto-day care and by the medical students who are too uncertain about her condition to talk to her as they would to any other adult. They 
haven't learned much about people with dementia although they may know a great deal about amyloid plaques or APOE4. So they tend to discount her. It takes a long time to understand what she is saying and their time is pretty limited. So they rush through their time with Mrs. Fabrique. What moral problem does the situation of Rosa Fabrique represent? How do the special features of her illness make it difficult for her to retain her adult status? How does she try to avoid stigma? Why is this a moral problem? How might gender shape the relationships she has with the staff? When I asked a group of participants at an adult day services center how they knew when someone respected them, one woman, with a diagnosis of Alzheimer's disease, practically jumped from her seat, exclaiming, "when they talk to me like I'm a real person!" A useful insight from Mrs. La Fontaine, an artist, who also happens to have Alzheimer's disease.

\section{Reaching to culture: the individual in culture and society}

These examples link the individual to society. I want to explore briefly the ethical implications of the social devaluing of older people, especially women, and people with disabilities (23). An often hidden ageismdirected at people who do not live up to the newest ideals of a healthy and successful aging-operates at the nexus of individual and society, the intangible site where individuals encounter cultural norms and political constraints. Because of its effect on moral identity and integrity, it has important and unexamined ethical implications. The social marginalization of many older people, their invisibility as others define their needs, and their relative powerlessness all have ethical implications. An older woman captured the feeling that expert discourse can create: "old age is a time of devastating losses: our health, our lifelong friends, our money, our status, our dearest friend of all, our spouse.
But we can handle all of these. We can tolerate the ravages of aging. But what we cannot tolerate, what we cannot stand, is for younger people to tell us what is best for us. We just cannot put up with that" (24).

Women have long done the invisible tasks that allowed others to flourish-husbands, children, and employers; yet, they achieved little moral approbation for these efforts. As women age, cultural marginalization becomes more pronounced. From the perspective of those who embody dominant cultural norms-the world of biomedicine, for example-old women often represent a disruption of the visual field; like others who are classed as abnormal, disabled, or otherwise different, the old come to be seen and evaluated as less-than (25).

What then is the ethical import of this bodily aging in this first year of the $21^{\text {st }}$ century? Henry's body was not only aging but it was damaged in ways that required a remaking of his self-valuation as well as the valuing of others. But even without physical or mental damage, the very appearance of the aging body and its "normal" limits would not matter if it were not critically tied to identity, to some notion of who we are, what we take as our ends or purposes, what values we hold dear. And identity has links to other morally important features of human life, in particular, the possibility for well-being. Roughly, human flourishing requires, in addition to identity, self-respect, selfknowledge, friendship, and confident agency (5). Thus, there are close connections between identity and other goods and normative ideals.

If the goals of identity (or a sense of the self) are so important in achieving other normative ideals, then we must consider the ethical implications of cultural norms and ideals. If the self is basically social as many social scientists and philosophers hold, then culture and other aspects of our social lives have much to do with identity creation and 
the ability to live morally satisfying lives. Social disregard, if not disdain, of aging represents constant threats to self-esteem and dignity. For older people, it often leads to the separation of "me" from the body, an ultimately defeatist strategy. Most cultures have a long way to go in creating conditions to support the psychological integration of mind and body.

Thus, many contemporary societies present problems for older people who are seeking a strong identity despite loss. This problem becomes confounded by the way culture shapes the impressions and reactions of others. Since there is no transparent encounter with another, societal ageism and its opposite-visions of successful or productive aging-consciously or unconsciously influence our encounters with each older person we meet. We carry impressions, images, and ideas, which shape our interactions with others. Watch yourself closely some time and reflect on your responses to that woman who shuffles along with her cane and her shopping bag.

Let me just use a few specific examples. Think for a moment about the 80 year old man, still living at home, but needing considerable help to do so hearing himself described as a "greedy geezer." Why haven't we-at least we North Americans-banished that word from our vocabulary? By the same token, think of that man-the 78 year old struggling with multiple disabilities-and recent efforts to promote cultural representations of aging as either "productive" or "successful." To the extent that all of us assess ourselves-at least to some degree-by cultural standards, criteria that immediately elicit their opposites cannot be the images that we want to sanctify. And no matter how carefully we ingest our vitamins, do weight-bearing exercises, eat a low-fat diet, and do whatever else the gurus of longlife tell us to do, our aging processes are not singularly within our control.
Where do all these assertions bring me? I stress these features of our encounters with the specific features of old age-physical, and mental changes, dependency and deathbecause they are what we resist most powerfully. While I do not want to return to earlier assumptions about old ageconveniently labeled the "decline and loss" paradigm-, I think we have gone so far in the other direction that we morally denigrate the old who cannot live up to the new stereotypes. Our problem is not reversing that former dominant paradigm and emphasizing its polar opposite-the mountain climbing grandfather and the kayaking greatgrandmother-but finding ways to accept that human well-being-though not necessarily without suffering-is possible even in the face of illness, loss, and death. So in our efforts to notice, to pay attention, we come to the realization that age will always be associated with death (unless the manufacturers of stem-cell created spare parts have their way) because in the normal course of things (at least in the last few decades) death comes to the old. Each person arrives at some point where she is more old than young-at least chronologically-and, for most of us, we feel our chronology physically (For the over 50s reading this, admit it-don't you get more tired that you did 20 years ago?). Even the postmodern, self-creating consumer of desert golf courses and Armani clothes becomes old, usually at the onset of some chronic condition that no amount of consumer fixes can remedy. No cane or the best-decorated walker can remove the public image of old age. But it is even simpler and more direct than that. This aging is very public because the bodily self that we put out into the world can neither be hidden nor denied $(26,27)$. Each time I go on the bus my brown hair generously sprinkled with gray and new facial lines, albeit gentle ones, accompany me and even though I weigh the same now as I did 20 years ago, no more trips to those Northern California "clothes 
optional" hot springs for this aging body.

I and each of us and the old person we will now attend to become old in a particular culture at a particular historical moment. And despite the power of that Armani blazer, even the prominent society women, becomes old, generally first in the eyes of others. Let us beware as we think of population aging of painting false scenarios for what will be the "new" aged.

We also come to see that the big tasks are cultural ones-that resisting ageism in whatever form it takes does not mean elevating an older person who is not old. I mean by that seemingly paradoxical statement, someone who at 75 looks and behaves like a 40 year old. Imagine how coercive that kind of standard is if you are 75 and feel like you are 80 and can hardly walk across the street, not because you abandoned the treadmill or the tennis courts but because you developed rheumatoid arthritis when you were 35 or because you have completed your second round of chemotherapy for breast cancer. In an effort to change the images of aging, I am afraid we have done just the opposite. Philosopher Sarah Ruddick notes, "in trying to create mutually helpful and respectful relationships in which we can fall and be caught 'with dignity,' we have at least as much to learn from elderly people who fail as from the vigorously healthy" (28, p. 59). So we wind up, if these observations make any sense at all, at the nexus of the individual and culture, the larger contextual framework for a conversation about ethics and aging. If we are to take ethics and aging as more than a set of rules or principles that we bestow upon the elderly in the form of rights-actually a relatively simple agenda- then culture is an important starting place and we are the individuals who help to constitute our cultures. I think our tasks are cut out for us.

\section{Conclusion}

How do we get to this place of attentiveness and all the actions that flow from it when we are concerned about the costs of medicine, the growing population of the elderly, and the general resistance to paying for the care of the stranger in our midst? I think we must acknowledge the real, the contemporary political situations in our countries without losing sight of what we would want and what it would take to live a denser, richer ethical life. "Without the light of language," historian Michael Ignatieff observed, "we risk becoming strangers to our better selves" (29, p. 142). We need to find a way for positive emotions, like compassion, and the concept of "cleaving" as Ruth did with Naomi in the Hebrew Scriptures or being one with another to reenter our public conversation. Such reentry can evoke a commitment to action by opening us to the suffering of others and accepting that our reactions to such suffering are fundamentally moral (30). Alertness to how the normative assumptions that support politics and policy and the power of ideology and culture become manifest in "ordinary" lives can become the foundation for a sustained ethical analysis of how background conditions mediate life's possibilities and reinforce conditions of inequality.

To close, I want to note problems-four factors that may confound our best efforts to behave in an ethical manner. One is the power relationships that contribute to domination and inequality in relations among people that threatens the very possibilities of ethical behavior. Two, institutional and organizational factors can often inhibit what we know is morally appropriate behavior and this danger accelerates as funding becomes more constrained. Three, caregivers who are not the beneficiaries of good care can rarely provide good care. This factor requires extra vigilance as we work with people who have the least autonomy and freedom of all- 
the nurses' aides and other frontline caregivers. And, fourth, as noted above, as a powerful cultural force, medicine itself helps create the moral values that older people feel they must uphold. Such culturally powerful messages, I suggest, have important, and not necessarily positive ethical implications. So in thinking about an ethics and aging we must pay attention to how medicine has shaped that experience in terms of beliefs, expectations, judgments, and promises and ask if this is indeed a vision that we support.

\section{References}

1. Baier A. Alternative Offerings to Asclepius?. Medical Humanities Review 1992; 6 (1): 919.

2. Komesaroff P. Introduction: Postmodern Medical Ethics. In: Komesaroff P. (ed.) Troubled bodies: Critical Perspectives on Postmodern Medical Ethics, and the Body. Durham, NC: Duke University Press; 1995. (p. 1-19).

3. Eliot T.S. Little Giddings. In: Four Quartets. San Diego, CA: Harcourt, Brace, Jovanovich; 1971.

4. Flanagan. O. Ethics Naturalized: Ethics as Human Ecology. In: May L, Friedman M, Clark A. (eds.) Mind and Morals: Essays on Ethics and Cognitive Science. Cambridge, MA: MIT Press; 1996. p. 19-44.

5. Flanagan O. Varieties of Moral Personality: Ethics and Psychological Realism. Cambridge, MA: Harvard University Press; 1991.

6. Kaufman S. The Ageless Self: Sources of meaning in later life. Madison, WI: University of Wisconsin Press; 1984.

7. Lustbader W. What's Worth Knowing. New York: Free Press; 2001.

8. Wendell S. Old Women Out of Control: Some thoughts on aging, ethics, and psychosomatic medicine. In : Walker MU. (ed) Mother Time; 1999. p.133-50.

9. Meyers D T. Miroir, Memoire, Mirage: Appearance, aging, and women. In: Walker
MU. (ed.). Mother Time: Women, Aging, and Ethics. Lanham, MD: Rowan and Littlefield; 1999. p. 23-41.

10. Shem S. House of God. Reissue. New York: Dell; 1981.

11. Ferenz L. The "asesthetics of dementia care": Some final thoughts from Tom Kitwood. Journal of Clinical Ethics 2000; 11 (1): 6972.

12. Moody HR. Ethics in an Aging Society. Baltimore: Johns Hopkins University Press; 1992.

13. Walker MU. Moral Understandings: A feminist study in ethics. New York: Routledge; 1998.

14. Collopy B. Safety and Independence: Rethinking some basic concepts in long-term care. In: McCullough L, Wilson N. (eds.) Long-Term Care Decisions: Ethical and conceptual dimensions. Baltimore. MD: Johns Hopkins University Press; 1995.

15. Waymack M. The Ethical Importance of Home Care. In: Holstein M, Mitzen P. (eds.). Ethics in Community-Based Elder Care. New York: Springer Pub., Forthcoming; 2001.

16. Kittay EF. Love's Labor: Essays on women, equality, and dependency. New York: Routledge; 1999.

17. Walker MU. Picking up pieces: lives, stories, and integrity. In: Meyers, D. (ed.) Feminists rethink the self. Boulder, CO: Westview Press; 1997. p. 62-84.

18. Holstein M. Reflections on death and dying. Academic Medicine 1997; 72 (10): 848-55.

19. Frankl V. Man's Search for Meaning. Rev.and upated. New York: Washington Square Press; 1998.

20. Morton B. Starting Out in the Evening. New York: Crown Publishers; 1998.

21. Murdock I. The Sovereignty of Good. London: Routledge; 1970.

22. Komesaroff P. From Bioethics to Microethics: Ethical Debate and Clinical Medicine. In: Komesaroff P. (ed.) Troubled Bodies: Critical perspectives on postmodern medical ethics, and the body. Durham, NC: Duke University Press; 1995. p. 62-86.

23. Walker MU (ed). Mother Time women, aging 
and ethics. Lanham, MD: Rowan and Littlefield; 1999.

24. Lustbader W. Counting on Kindness: The dilemmas of dependency. New York: The Free Press; 1991.

25. Furman F. Facing the Mirror: Old women and beauty shop culture. New York: Routledge; 1999.

26. Miller N. The Marks of Time. In: Woodward K. (ed.) Figuring Age: Women, bodies, generations. Bloomington, IN: University of Indiana Press; 1999.

27. Featherstone M, Hepworth M. The Mask of Ageing and the Postmodern Life/Course. In:
Featherstone M, Hepworth, Turner B. (eds.) The Body: Social processes and cultural theory. London: Sage; 1990. p. 371-89.

28. Ruddick S. Virtues and Age. In: Walker MU. Mother Time. 1999. p. 45-60.

29. Ignatieff M. The Needs of Strangers: An essay on privacy, solidarity, and the Politics of Being Human. New York: Penguin Books; 1984.

30. Zoloth L. Health Care and the Ethics of Encounter: A jewish discussion of social justice. Chapel Hill, NC: University of North Carolina Press; 1999. 